\title{
Activation of Intercellular Adhesion Molecule 1 Expression by Helicobacter pylori Is Regulated by NF-кB in Gastric Epithelial Cancer Cells
}

\author{
NAOKI MORI,${ }^{1 *}$ AKIHIRO WADA, ${ }^{2}$ TOSHIYA HIRAYAMA, ${ }^{2}$ THOMAS P. PARKS, ${ }^{3}$ \\ CHRISTIAN STRATOWA, ${ }^{4}$ AND NAOKI YAMAMOTO ${ }^{1}$ \\ Department of Preventive Medicine and AIDS Research ${ }^{1}$ and Department of Bacteriology, ${ }^{2}$ Institute of Tropical \\ Medicine, Nagasaki University, Nagasaki, Japan; Department of Inflammatory Diseases, Boehringer Ingelheim \\ Pharmaceuticals, Incorporated, Ridgefield, Connecticut ${ }^{3}$; and Ernst Boehringer Institut, Vienna, Austria ${ }^{4}$
}

Received 22 September 1999/Returned for modification 19 November 1999/Accepted 28 December 1999

\begin{abstract}
Interactions between leukocytes and epithelial cells may play a key role in Helicobacter pylori-associated gastric mucosal inflammation. This process is mediated by various cell adhesion molecules. The present study examined the molecular mechanisms leading to $\mathrm{H}$. pylori-induced epithelial cell intercellular adhesion molecule-1 (ICAM-1; also called CD54) expression. Coculture of epithelial cells with cytotoxin-associated gene pathogenicity island-positive ( $c a g \mathrm{PAI}^{+}$) $\mathrm{H}$. pylori strains, but not with a cag $\mathrm{PAI}^{-}$strain or $\mathrm{H}$. pylori culture supernatants, resulted in upregulation of steady-state mRNA levels and cell surface expression of ICAM-1. Coculture with $H$. pylori induced an increase in luciferase activity in cells which were transfected with a luciferase reporter gene linked to the $5^{\prime}$-flanking region of the ICAM-1 gene. $H$. pylori activated the ICAM-1

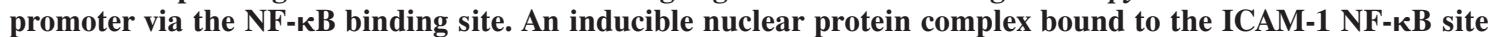

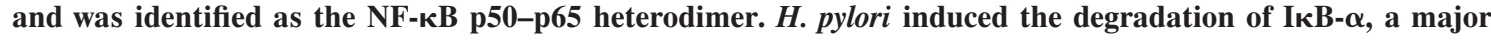
cytoplasmic inhibitor of NF- $\mathrm{B}$, and stimulated the expression of $\mathrm{I} \kappa \mathrm{B}-\alpha \mathrm{mRNA}$. Pretreatment of epithelial cells with pyrrolidine dithiocarbamate, which blocks NF-кB activation, inhibited $H$. pylori-induced ICAM-1 expression. THP-1 macrophagic cells, peripheral blood mononuclear cells, and purified neutrophils adhered to $H$. pylori-infected epithelial cells to a greater extent than to uninfected cells. These results show that $H$. pylori directly induces expression of ICAM-1 on gastric epithelial cells in an NF-кB-dependent manner that may support leukocyte attachment during inflammation.
\end{abstract}

Several lines of evidence implicate Helicobacter pylori in the pathogenesis of active chronic gastritis, peptic ulcer disease, gastric carcinoma, and gastric B-cell lymphoma, even though most $H$. pylori infections are asymptomatic (7, 29, 31). Although the exact mechanisms by which $H$. pylori infection results in gastroduodenal pathology are unclear, current opinion holds that $H$. pylori can induce an acute inflammatory reaction consisting of leukocyte infiltration and epithelium damage (4, 14). However, because $H$. pylori generally adheres to gastric epithelial cells without invading the epithelium, it is presumed that an interaction between bacteria and host epithelial cells may initiate $H$. pylori-induced inflammation. Because of the strong inflammatory response to $H$. pylori infections, the role of inflammatory cytokines was investigated. It was shown that mucosal biopsy specimens from patients with $H$. pylori infections contain significantly elevated levels of interleukin-1 $\beta$ (IL$1 \beta)$, IL-6, tumor necrosis factor alpha (TNF- $\alpha)$, and IL-8 compared to those in specimens from uninfected individuals $(9,11$, 13, 30). Exposure of gastric epithelial cell lines to $H$. pylori induced the secretion of a potent leukocyte chemotactic and activating factor, IL-8 $(19,32)$. The association of IL-8 with $H$. pylori infection was further suggested by elevated levels of IL-8 in gastric epithelial cells in vivo (9), in tissue homogenates of mucosal biopsy specimens $(13,27)$, and in in vitro-cultured

* Corresponding author. Mailing address: Department of Preventive Medicine and AIDS Research, Institute of Tropical Medicine, Nagasaki University, 1-12-4 Sakamoto, Nagasaki 852-8523, Japan. Phone: 81-95-849-7846. Fax: 81-95-849-7805. E-mail: n-mori@net.nagasaki-u .ac.jp. biopsy specimens from patients with $H$. pylori-associated gastritis and peptic ulcers (30).

Cell-cell interactions play an important and probably central role in a large number of immunological processes in physiological and pathological conditions. These interactions are at least partially mediated by various cell adhesion molecules. Expression of cell adhesion molecules on gastric epithelial cells may participate in leukocyte homing and epithelial-cell adhesion in $H$. pylori-associated mucosal inflammation. In the context of $H$. pylori infection, the production of chemoattractive cytokines and cell adhesion molecules could provide a means of recruiting and retaining inflammatory cells within the gastric epithelial layer, contributing to $H$. pylori-mediated tissue injury.

In this study, we show that gastric epithelial cells have the ability to initiate changes associated with inflammation through the upregulation of intercellular adhesion molecule-1 (ICAM-1) after infection with $H$. pylori. Furthermore, we identify the molecular mechanism of ICAM-1 gene activation following $H$. pylori infection in gastric epithelial cell cultures. These data support the theory that the gastric epithelium plays an active role in initiating inflammation as part of the host response to $H$. pylori infection.

\section{MATERIALS AND METHODS}

Bacterial strains. The H. pylori strain ATCC 49503 was used in most of this study. Other clinical strains (OHPC0001, OHPC0002, and OHPC0003), isolated from chronic gastritis patients, were kind gifts of T. Kitahora (Ohkura Hospital, Tokyo, Japan). The presence of the cag pathogenicity island (PAI) and vacA in these strains was determined by PCR using specific sets of primers $(1,37) . H$. pylori strains were recovered from frozen stocks by seeding them on a blood agar plate (Mueller-Hinton II agar with $7 \%$ horse blood) at $37^{\circ} \mathrm{C}$ for 3 days under 
microaerophilic conditions $\left(10 \%, \mathrm{O}_{2}\right.$ and $\left.10 \% \mathrm{CO}_{2}\right)$ generated with Anaeropack Campylo (Mitsubishi Gas Chemicals Co., Tokyo, Japan). Bacteria harvested from the plates by using cotton swabs were suspended in $200 \mathrm{ml}$ of brain heart infusion broth containing $10 \%$ fetal calf serum and were then liquid-cultured at $37^{\circ} \mathrm{C}$ for 3 days with vigorous shaking in a controlled microaerophilic atmosphere. Bacteria were harvested from a broth culture by centrifugation and were resuspended at the indicated concentrations in antibiotic-free medium. At this time, bacteria reached a concentration of $4 \times 10^{8} \mathrm{CFU} / \mathrm{ml}$. All procedures were performed with the approval of the respective institutional biosafety review committees and in compliance with their guidelines for biohazards.

Cell culture. A panel of epithelial cell lines was cultured in RPMI 1640 or Ham's F-12 medium supplemented with $10 \%$ fetal bovine serum (GIBCO Laboratories, Grand Island, N.Y.) and antibiotics (50 U of penicillin $/ \mathrm{ml}$ and $50 \mu \mathrm{g}$ of streptomycin $/ \mathrm{ml})$. In these experiments, the gastric epithelial cancer cell lines MKN45, AGS, and KATO III were used.

Peripheral blood mononuclear cells (PBMCs) and neutrophils were isolated from venous blood of healthy adults using standard dextran sedimentation and gradient separation on Ficoll-Hypaque (Pharmacia LKB, Uppsala, Sweden).

Expression of ICAM-1. To measure ICAM-1 expression on epithelial cells after bacterial infection, epithelial-cell monolayers were infected by adding $H$. pylori (final concentrations, 500 organisms/cell). Preliminary studies with MKN45 cells using varying numbers of $H$. pylori organisms indicated that higher concentrations of bacteria induced the death of epithelial cells, as determined by morphological analysis. In the same series of experiments, MKN45 cells were cocultured with culture supernatants from $H$. pylori. In some experiments, MKN45 cells were treated with pyrrolidine dithiocarbamate (PDTC; 20, 50, or $100 \mu \mathrm{M})$, which inhibits NF- $\mathrm{B}$ activation $(5,21,28,38)$. After $1 \mathrm{~h}$ of PDTC exposure, the cells were infected with $H$. pylori. For surface expression of ICAM-1, cells were harvested, washed, and stained using the fluorescein isothiocyanate-conjugated mouse anti-CD54 monoclonal antibody (MAb) or the isotypic control immunoglobulin G1 (IgG1) (Coulter Immunology, Hialeah, Fla.). Fluorescence was measured on a FACScan flow cytometer (Becton Dickinson, San Jose, Calif.)

Northern blot analysis. Gastric epithelial cells were cocultured with $H$. pylori for the indicated times. Total cellular RNA was extracted from the cells using Trizol as described by the manufacturer (GIBCO-BRL, Gaithersburg, Md.), and the amount of total RNA was determined by measuring the absorbance at 260 $\mathrm{nm}$. Twenty micrograms of total RNA was electrophoresed on a formaldehydeagarose gel and was transferred onto a nylon filter. The filters were prehybridized (0.5 M sodium phosphate- $0.1 \%$ bovine serum albumin- $7 \%$ sodium dodecyl sulfate [SDS]-100 $\mu \mathrm{g}$ of salmon testis DNA $/ \mathrm{ml}-100 \mu \mathrm{g}$ of yeast RNA $/ \mathrm{ml}$ ) for $2 \mathrm{~h}$ at $65^{\circ} \mathrm{C}$ and then hybridized overnight with the following $\left[\alpha-{ }^{32} \mathrm{P}\right] \mathrm{dCTP}$ radiolabeled probes: cDNA of human ICAM-1 (kindly provided by T. K. Kishimoto, Boehringer Ingelheim Pharmaceuticals, Inc., Ridgefield, Conn.), ІкB- $\alpha$ (kindly provided by D. W. Ballard, Vanderbilt University School of Medicine, Nashville, Tenn.) (15), and glyceraldehyde-3-phosphate dehydrogenase (GAPDH) (3). Radiolabeled probes were generated using a Megaprime DNA Labeling system (Amersham, Arlington Heights, Ill.).

Western blot analysis. The antibody used for Western blot analysis was a rabbit polyclonal antibody to IкB- $\alpha$, C-21 (Santa Cruz Biotechnology Inc., Santa Cruz, Calif.). Cells were lysed by incubation in radioimmunoprecipitation assay buffer $(0.5 \%$ sodium deoxycholate, $1 \%$ Nonidet P-40, $0.1 \%$ SDS, $66 \mu \mathrm{g}$ of aprotinin/ml, $100 \mu \mathrm{g}$ of phenylmethylsulfonyl fluoride/ml, and $1 \mathrm{mM}$ sodium orthovanadate) for $30 \mathrm{~min}$ at $4^{\circ} \mathrm{C}$. Equal amounts $(50 \mu \mathrm{g})$ of protein from cell lysates were electrophoresed on SDS-10\% polyacrylamide gels and transferred to polyvinylidine difluoride membranes. The membranes were blocked with Tris-buffered saline-Tween $(0.05 \%)$ containing 3\% nonfat dried milk overnight at $4^{\circ} \mathrm{C}$, and then they were incubated for 45 min with a 1:500 dilution of the antibody. The membranes were washed with Tris-buffered saline-Tween, incubated with a 1:1,000 dilution of horseradish peroxidase-conjugated anti-rabbit immunoglobulin (Amersham), and then developed using enhanced chemiluminescence reagents (Amersham) and fluorography.

Luciferase assay. The various ICAM-1 promoter constructs have been described previously $(25,36)$. NF- $\mathrm{kB}-\mathrm{LUC}$ is a luciferase expression plasmid controlled by five copies of the IL-2 receptor (IL-2R) $\alpha$ chain gene $\kappa \mathrm{B}$ element (a kind gift from J. Fujisawa, Kansai Medical University, Osaka, Japan) (34). For the luciferase assay, $7 \times 10^{5}$ MKN45 cells were transfected with $5 \mu \mathrm{g}$ of each luciferase vector along with $0.1 \mu \mathrm{g}$ of pRL-TK, an internal control Renilla luciferase expression vector (Toyo Ink Co., Tokyo, Japan), using the Calcium Phosphate Mammalian Cell Transfection kit ( 5 Prime $\rightarrow 3$ Prime, Inc., Boulder, Colo.) according to the manufacturer's recommendations. After $24 \mathrm{~h}$, the transfected cells were divided into two parts, and H. pylori (final concentration, 500 organisms/cell) was added separately to each part. After an additional $6 \mathrm{~h}$ of incubation, cell lysates were prepared using PicaGene Dual (Toyo Ink Co.) Twenty microliters of the cell lysates was assayed for both firefly and Renilla luciferase activity using the dual-reporter assay system indicated above in a Lumat model LB9505C luminometer (Berthold, Bad Wildbad, Germany). The firefly luciferase activity was normalized to the Renilla luciferase activity, and the fold stimulation was calculated as the ratio of the value for $H$. pylori-infected cells to that for uninfected cells.

Electrophoretic mobility shift assay (EMSA). Nuclear proteins were extracted from epithelial cells incubated in the presence or absence of $H$. pylori $(500$ organisms/cell) as described by Antalis and Godbolt (2) with modifications. Five-microgram aliquots of nuclear proteins were incubated for $15 \mathrm{~min}$ at room temperature with $1 \mathrm{ng}$ of an $\left[\alpha-{ }^{32} \mathrm{P}\right] \mathrm{dCTP}-$ and $\left[\alpha-{ }^{32} \mathrm{P}\right] \mathrm{dATP}-l a b e l e d \mathrm{NF}-\kappa \mathrm{B}$ binding site of the ICAM-1 gene (5'-tcgaTAGCTTGGAAATTCCGGAGC-3'; lowercase letters indicate residues added for labeling purposes) and $1 \mu \mathrm{g}$ of poly(dI-dC) (Pharmacia, Piscataway, N.J.) in $20 \mu \mathrm{l}$ of a solution containing 10 $\mathrm{mM}$ Tris- $\mathrm{HCl}$ (pH 7.5), $50 \mathrm{mM} \mathrm{NaCl}, 1 \mathrm{mM}$ EDTA, $1 \mathrm{mM}$ dithiothreitol, and 5\% glycerol. In competition studies, a 100-fold excess of the unlabeled ICAM-1 кB probe, oligonucleotides containing a mutated NF-кB binding site $\left(5^{\prime}\right.$-tcgaTAG CTTCTAGATTAGGGAGC-3') (mutated sequences are underlined), or oligonucleotides bearing the IL-2R $\alpha$ chain gene NF- $\mathrm{kB}$ site $\left(5^{\prime}\right.$-gatcCGGCAGGG GAATCTCCCTCTC-3') was included in the reaction mixture along with the radiolabeled probe. In some experiments, nuclear proteins were preincubated with $2 \mu \mathrm{g}$ of antibodies to p65, p50, p52, or c-Rel (Santa Cruz Biotechnology Inc.) for $45 \mathrm{~min}$ at room temperature before addition of the labeled probe. The mixtures were loaded onto a $4 \%$ polyacrylamide gel with $0.25 \times$ Tris-borate buffer. After electrophoresis, gels were dried and analyzed by autoradiography.

Adhesion assay. MKN45 cells were plated at confluent density $\left(10^{5}\right.$ cells/well $)$ in flat-bottom wells of a 96-well microtiter plate. THP-1 cells, PBMCs, or neutrophils were suspended in serum-free RPMI 1640 containing $5 \mu \mathrm{M} 2^{\prime}$, 7'-bis(2-carboxyethyl-5)- and 2',7'-bis-(2-carboxyethyl-6)-carboxyfluorescein, acetoxymethyl ester (BCECF-AM) (Dojin Chemicals, Kumamoto, Japan). After incubation for $45 \mathrm{~min}$ at $37^{\circ} \mathrm{C}$, these cells were washed with phosphate-buffered saline (PBS) and then resuspended in culture medium. Before adhesion experiments, cells either remained untreated or were incubated at $4^{\circ} \mathrm{C}$ for $1 \mathrm{~h}$ in the presence of either an anti-CD18 MAb, an anti-CD54 MAb, or control IgG1 (Immunotech, Marseille, France). Subsequently BCECF-labeled THP-1 cells $\left(2 \times 10^{5}\right.$ cells/well $)$, PBMCs $\left(10^{6}\right.$ cells/well $)$, or neutrophils $\left(10^{6}\right.$ cells/well $)$ were deposited on unstimulated or H. pylori-stimulated MKN45 cell monolayers for 30 min at $37^{\circ} \mathrm{C}$. Each experiment was run in quadruplicate. Nonadherent cells were removed by inverting the plates and washing with PBS. Adherent cells were solubilized with $1 \%$ Nonidet P-40 in PBS, and the fluorescence intensity of each well was measured with a Fluoroscan II (Labsystems, Helsinki, Finland).

\section{RESULTS}

H. pylori induces ICAM-1 expression in human gastric epithelial cell lines. We first examined the capacity of several gastric epithelial cell lines to express ICAM-1 upon coculture with live H. pylori. AGS and KATO III cells constitutively expressed cell surface ICAM-1 and ICAM-1 mRNA, whereas MKN45 cells did not (Fig. 1A and B; also data not shown). Coculture with $H$. pylori significantly enhanced steady-state levels of ICAM-1 mRNA in MKN45 cells and cell surface expression of ICAM-1 by these cells (Fig. 1A and B). Similar results were also obtained using AGS and KATO III cells (data not shown). Since the $H$. pylori-induced ratio of enhancement of ICAM-1 expression was greatest on MKN45 cells, we used MKN45 cells in the following experiments. We next examined the dose dependency of $H$. pylori-induced ICAM-1 expression on MKN45 cells. The cell surface expression of ICAM-1 was significantly increased after the addition of $0.5 \mathrm{H}$. pylori organism/cell (Fig. 1C). The highest level of ICAM-1 expression was observed after infection with $50 \mathrm{H}$. pylori organisms/cell (Fig. 1C).

Flow cytometry studies indicated that MKN45 cells started to express a significant amount of ICAM-1 $6 \mathrm{~h}$ after the initiation of coculture with the bacteria (Fig. 1B). ICAM-1 mRNA levels clearly increased $2 \mathrm{~h}$ after $H$. pylori infection, reached maximal levels at $6 \mathrm{~h}$, and remained elevated at least $24 \mathrm{~h}$ following infection (Fig. 1A). H. pylori culture supernatants failed to induce ICAM-1 mRNA or cell surface expression on MKN45 cells (Fig. 1B and data not shown).

$H$. pylori strains differ in their abilities to induce ICAM-1 expression. Since recent studies indicated that expression of multiple genes in the cag PAI is necessary for cytokine production by gastric epithelial cells in vitro $(6,35)$, we examined the abilities of several $H$. pylori strains to induce ICAM-1 expression. All isolates were positive for $\operatorname{vac} A$ (1) irrespective of ability to induce ICAM-1 expression (Fig. 2). Strain OHPC0002, which totally lacked the cag PAI, induced ICAM-1 mRNA and cell surface expression at levels consid- 

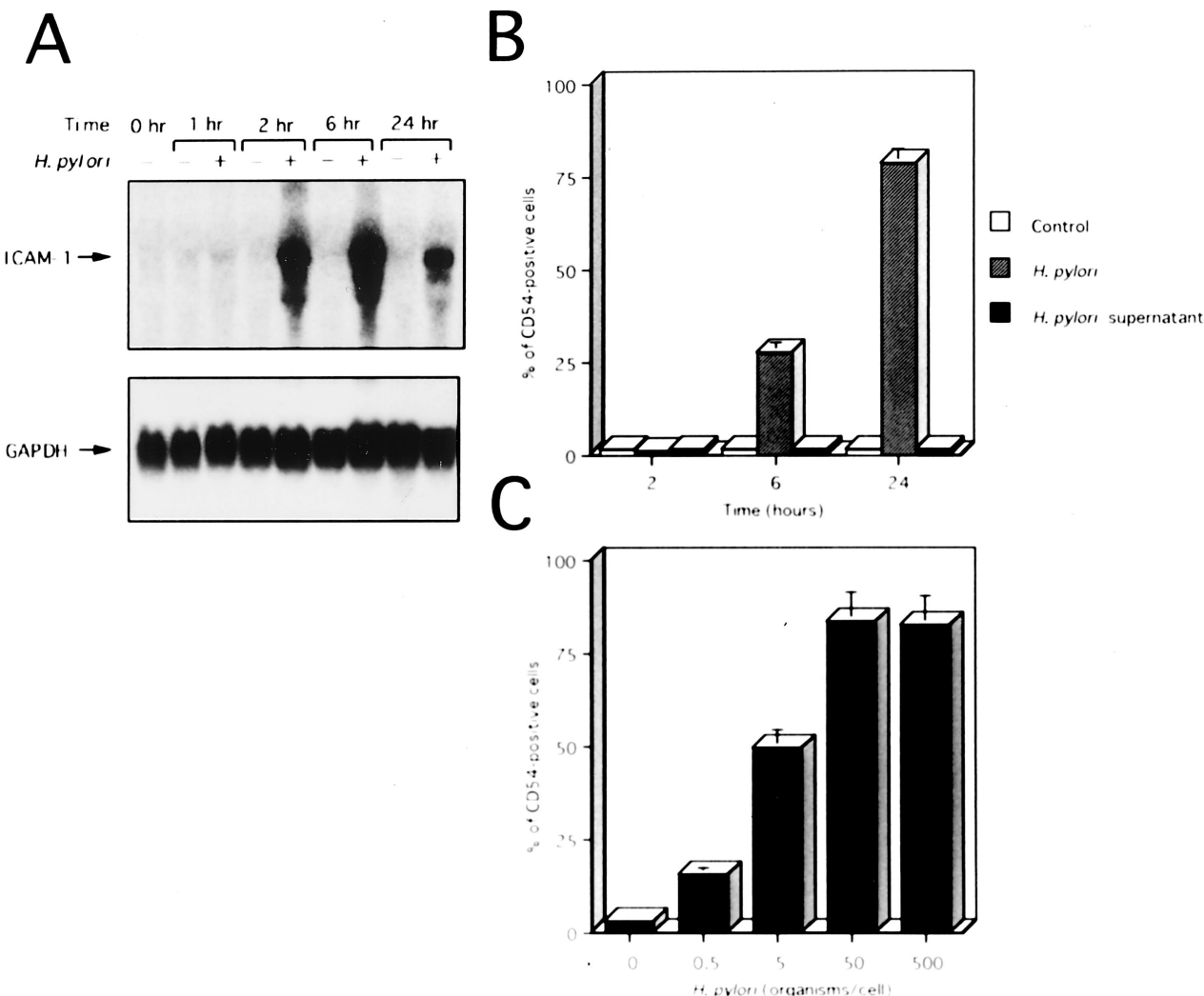

FIG. 1. ICAM-1 expression on a gastric epithelial cell line, MKN45. (A) Time course of $H$. pylori-induced ICAM-1 mRNA expression by Northern blot analysis. RNA was isolated from control $(-)$ and $H$. pylori (500 organisms/cell)-infected (+) MKN45 cells at the indicated times. Equal loading was assessed by hybridization of stripped blots with a probe for GAPDH. (B) Time course of cell surface expression of ICAM-1 on MKN45 cells exposed to $H$. pylori or $H$. pylori culture supernatants. MKN45 cells were cultured for the indicated times in culture medium (control), in the presence of $H$. pylori, or in the presence of $H$. pylori culture supernatants. After cell harvest, ICAM-1 expression on the cells was determined by fluorescence-activated cell sorter (FACS) analysis. Representative results are shown as means \pm standard deviations (SD) calculated from the results of three independent experiments. (C) H. pylori infection increases cell surface expression of ICAM-1 on MKN45 cells in a dose-dependent fashion. MKN45 cells were infected with varying concentrations of $H$. pylori, and ICAM-1 levels were measured by FACS analysis on cells harvested after $24 \mathrm{~h}$. Representative results are shown as means \pm SD calculated from the results of three independent experiments.

erably lower than those of strains ATCC 49503, OHPC0001, and OHPC0003, containing the entire cag PAI (37) (Fig. 2). These results suggest that the $H$. pylori cag PAI may play an important role in the induction of ICAM-1 expression, which parallels a previously reported observation on IL-8 expression $(6,35)$.

Activation of the ICAM-1 promoter by $\boldsymbol{H}$. pylori. To confirm that $H$. pylori-induced ICAM-1 upregulation occurred by activating gene transcription, the ICAM-1 5'-flanking region was analyzed with promoter/reporter gene constructs. MKN45 cells were transiently transfected with a plasmid, pBHluc1.3, which contains 1,344 bp of the ICAM-1 upstream region $(-1,353$ to -9 relative to the start of transcription), directing expression of the firefly luciferase reporter gene, and the transfected cells were then stimulated with $H$. pylori. Stimulation of MKN45 cells with $H$. pylori resulted in a 6.6-fold increase in luciferase activity, whereas the negative-control vector, pBHlucOL1, showed only low background activity (Fig. 3B). Strains OHPC0001 and OHPC0003 induced ICAM-1 promoter activity to similar levels. However, strain OHPC0002, devoid of $\mathrm{cag}$ PAI, and $H$. pylori ATCC 49503 culture supernatants were not found to increase ICAM-1 promoter activity (data not shown). These results indicated that the interaction with $H$. pylori induces ICAM-1 expression on MKN45 cells at the level of transcription.
To locate the cis-regulatory element(s) present within the $5^{\prime}$-flanking sequence of the ICAM-1 promoter that confers $H$. pylori responsiveness, we transiently transfected a series of pBHluc1.3 mutants with $5^{\prime}$ deletions of various lengths (the largest mutant beginning with bp -941 and the smallest beginning with bp -136) into MKN45 cells (Fig. 3A). High levels of induction were observed with the reporter constructs containing ICAM-1 5'-flanking sequence starting with position $-1,353$ (pBHluc1.3) to position -353 (construct D). However, further deletion to -136 (construct $\mathrm{E}$ ) resulted in a complete loss of $H$. pylori-induced promoter activity. It was apparent that the ICAM-1 5'-flanking sequence between -353 and -136 was required for the promoter to respond to $H$. pylori. To further investigate this $H$. pylori-responsive region, the sequence spanning bp -445 to -289 was cloned into construct $E$, resulting in construct $\mathrm{P}$. This was not induced by $H$. pylori. Therefore, we concluded that the region of the ICAM-1 promoter most critical for $H$. pylori induction in gastric epithelial cells was located between -289 and -136 .

Sequence analysis of the $H$. pylori-responsive region between -289 and -136 revealed potential binding sites for five transcription factors, AP-1 (-284 to -278$)$, Sp1 ( -206 to -201$)$, C/EBP ( -199 to -196$)$, Ets ( -153 to -150$)$, and NF-кB $(-187$ to -178$)$. Hou et al. (18) and Ledebur and Parks (25) demonstrated that TNF- $\alpha$-induced activation of the ICAM-1 


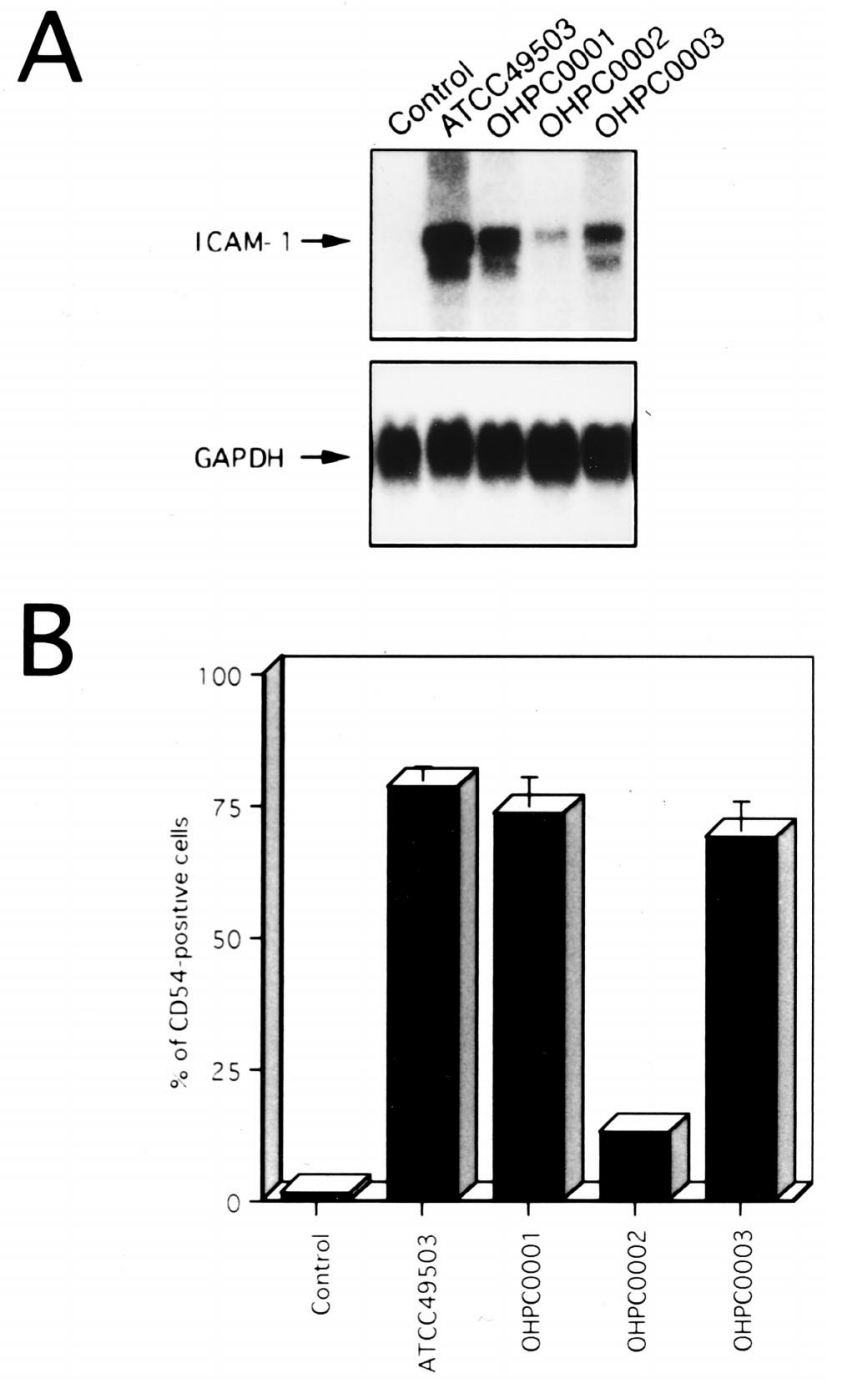

FIG. 2. ICAM-1 induction on MKN45 cells by cag $\mathrm{PAI}^{+}$and cag $\mathrm{PAI}^{-} H$. pylori strains. (A) cag $\mathrm{PAI}^{+} H$. pylori strains show induced ICAM-1 mRNA expression in MKN45 cells compared with a cag $\mathrm{PAI}^{-} H$. pylori strain. Total RNA was extracted from cells cocultured with $H$. pylori for $6 \mathrm{~h}$ and used for Northern blot analysis. Equal loading was assessed by hybridization of stripped blots with a probe for GAPDH. (B) Cell surface expression of ICAM-1 on MKN45 cells was determined by fluorescence-activated cell sorter analysis. MKN45 cells were cultured for $24 \mathrm{~h}$ in culture medium (control) or in the presence of $H$. pylori. Representative results are shown as means \pm standard deviations calculated from the results of three independent experiments.

promoter required the NF- $\mathrm{B}$ site. In order to determine the functional importance of the NF- $\mathrm{NB}$ site, transient transfections with mutant ICAM-1 promoter/luciferase reporter gene constructs with specific mutations in either the NF- $\mathrm{BB}$ (designated pGL1.3 $\mathrm{KB}^{-}$) or the Ets (designated pGL1.3Ets ${ }^{-}$) binding site (25) were performed (Fig. 3C). Mutation of the NF-кB site in the ICAM-1 promoter significantly reduced $H$. pylorimediated luciferase activity in gastric cells, whereas the Ets site mutation had no effect (Fig. 3D). These experiments indicated that activation of the ICAM-1 promoter in MKN45 cells in response to $H$. pylori stimulation required an intact binding site for NF-кB.

Stimulation with $H$. pylori induces a single predominant $\kappa B$ binding complex. Transient transfection experiments with wild-type and mutant ICAM-1 promoter/luciferase reporter gene constructs indicated that the NF- $\mathrm{BB}$ site is essential for activation by $H$. pylori in MKN45 cells. To determine whether the increase in ICAM-1 expression seen in H. pylori-stimulated gastric epithelial cells was related to an alteration of NF-кB DNA binding activity, nuclear extracts from gastric epithelial cells were prepared, and EMSA was performed using the ICAM-1 promoter NF- $\mathrm{B}$ element as a probe. Figure 4A shows the results for MKN45 cell nuclear extracts. Control MKN45 cell nuclear extracts contained little activated NF-кB (Fig. 4A, lane 1). A single $\kappa \mathrm{B}$ binding complex was observed in MKN45 cells after stimulation with $H$. pylori (Fig. 4A). Infection of KATO III and AGS cells with $H$. pylori resulted in NF- $\kappa \mathrm{B}$ activation similar to that observed in MKN45 cells (data not shown). NF- $\mathrm{B}$ activation was first evident at $30 \mathrm{~min}$ (Fig. 4A, lane 3) and appeared to be maximal at $1 \mathrm{~h}$ after $H$. pylori infection (Fig. 4A, lane 4). The levels of active NF-кB in nuclear extracts prepared from MKN45 cells after $2 \mathrm{~h}$ of exposure to $H$. pylori culture supernatants were similar to those in the control (data not shown). The specificity of this inducible $\kappa \mathrm{B}$-binding factor was confirmed by competition analysis with unlabeled oligonucleotides containing the ICAM-1 NF- $\mathrm{B}$ site, the IL-2R $\alpha$ gene NF-кB site, or an ICAM-1 NF-кB site with a point mutation. NF-кB proteins appeared to mediate this $H$. pylori-induced binding, since unlabeled wild-type ICAM-1 (Fig. 4B, lane 3) or IL-2R $\alpha \kappa$ B (lane 4), but not a mutant $\kappa \mathrm{B}$ oligonucleotide (lane 5), effectively competed for binding to the NF- $\mathrm{B}$ complex.

To identify the subunit composition of the NF-кB DNA binding complex, antibodies to NF- $\mathrm{B}$ family members $\mathrm{p} 65$, c-Rel, p50, and p52 were preincubated with the nuclear extracts from MKN45 cells and used in supershift analysis (Fig. 4C). Anti-p65 specifically recognized the stimulated $\kappa \mathrm{B}-\mathrm{DNA}$ binding complex, resulting in supershifted complexes (Fig. 4C, lane 4). Preincubation with anti-c-Rel or anti-p52 did not affect the $\kappa \mathrm{B}$ binding complex (Fig. $4 \mathrm{C}$, lanes 5 and 6), but preincubation with anti-p50 resulted in the formation of a partially supershifted complex (Fig. 4C, lane 3). These results suggest that in MKN45 cells, an NF-кB p65-p50 heterodimer, and possibly a p65 homodimer, is rapidly induced in response to $H$. pylori infection.

The NF-кB site is sufficient to mediate cag $\mathrm{PAI}^{+}$straininduced gene activation. Since it has been previously shown that cag $\mathrm{PAI}^{+}$strains induce significantly more IL- 8 mRNA and protein than do cag $\mathrm{PAI}^{-}$strains $(8,10,32)$, we sought to ascertain whether the difference between the abilities of different $H$. pylori strains to induce ICAM-1 expression was related to their abilities to activate NF-кB (Fig. 5A). NF-кB DNA binding activity was markedly induced by cag $\mathrm{PAI}^{+} H$. pylori strains (Fig. 5A, lanes 2, 3, and 5) compared to the cag $\mathrm{PAI}^{-}$strain (lane 4).

To further determine whether the NF-кB site was sufficient for activation by $H$. pylori, a reporter construct driven by an NF- $\kappa$ B element was compared (Fig. 5B). The construct $\kappa \mathrm{B}-$ LUC, which contains five tandem repeats of the NF-кB site, was markedly stimulated by cag $\mathrm{PAI}^{+} H$. pylori strains, whereas infection of MKN45 cells with a cag $\mathrm{PAI}^{-}$strain resulted in only a slight increase in reporter activity (Fig. 5B). These results demonstrate that the $\mathrm{NF}-\kappa \mathrm{B}$ site is sufficient for $c a g$ PAI-specific activation of $H$. pylori-induced ICAM-1 gene expression.

Degradation of IкB- $\alpha$ by $\boldsymbol{H}$. pylori. Since signal-induced proteolytic degradation of I $\mathrm{KB}-\alpha$ precedes the appearance of NF-кB DNA binding activity, we determined whether IкB- $\alpha$ was degraded in MKN45 cells that were stimulated by $H$. pylori. Kinetic analysis of $H$. pylori-induced degradation of ІкB- $\alpha$ in 


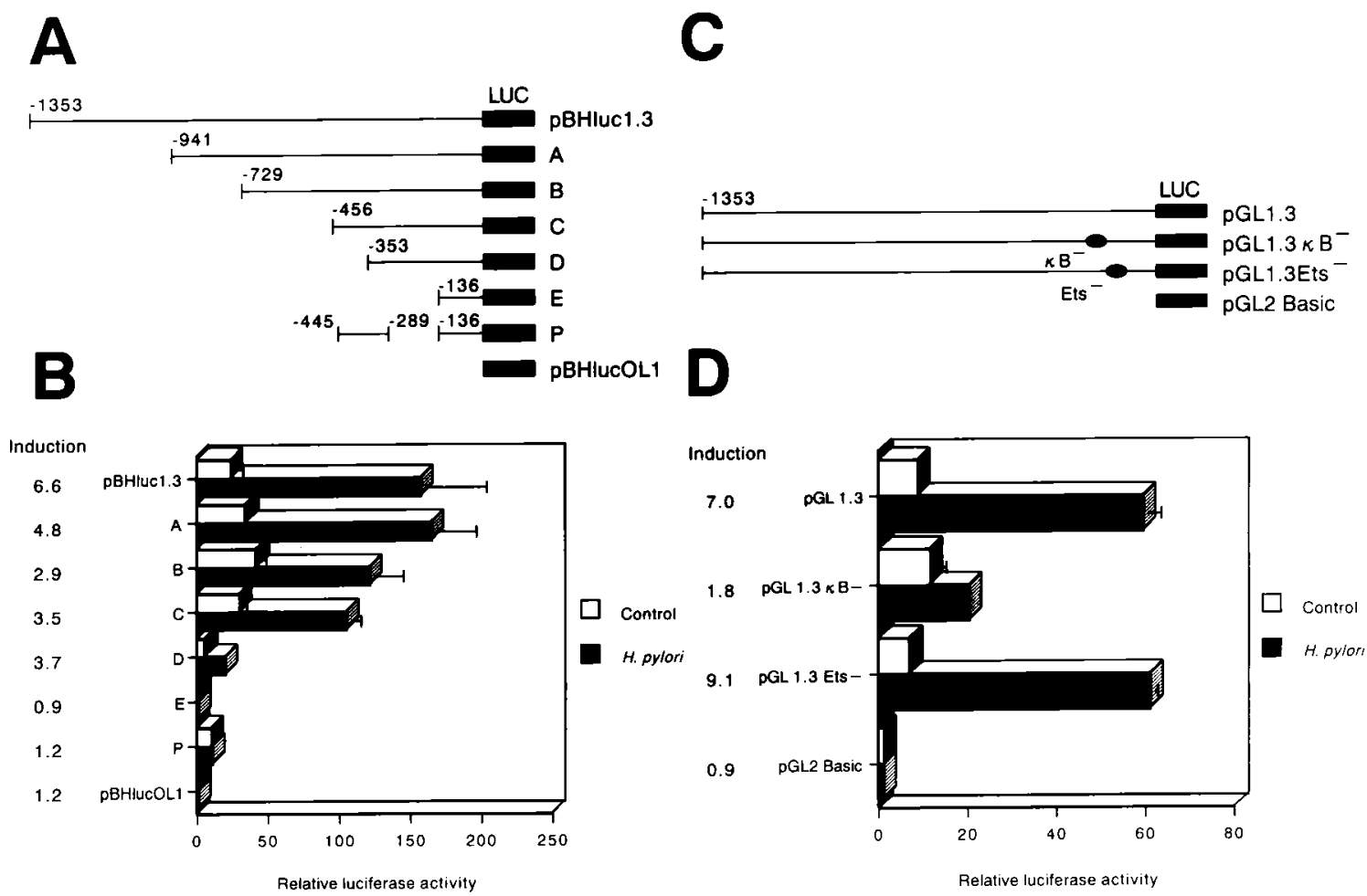

FIG. 3. Identification of a critical $H$. pylori-responsive region of the ICAM-1 promoter. (A) A series of constructs containing $5^{\prime}$-deletion mutants and a fusion construct linked to the firefly luciferase gene (LUC) were tested for transcriptional activity after transient transfection into MKN45 cells using calcium phosphate. The endpoints of fragments are indicated relative to the transcription start site. Twenty-four hours after transfection, one-half of the transfectants were stimulated with $H$. pylori for $6 \mathrm{~h}$. The cells were then lysed and assayed for luciferase activity. The luciferase activity of individual transfectants was subsequently normalized to the Renilla luciferase activity. (B) The normalized relative luciferase activities corresponding to each construct transiently expressed in MKN45 cells that were left untreated or induced with $H$. pylori are shown. The activity of cells transfected with pBHlucOL1 without further treatment was designated 1 . Average stimulated values were divided by average unstimulated values to give the induction ratios reported. Representative results are shown as means \pm standard deviations (SD) calculated from the results of three independent experiments. (C) The ICAM-1 кB and Ets sites were mutated in the context of the full-length construct, pGL1.3. (D) Mutation of the NF- $\mathrm{B}$ site suppresses $H$. pylori-induced ICAM-1 promoter activity. All constructs were transiently transfected into MKN45 cells with the control plasmid, pRL-TK, and the cells were subsequently infected with $H$. pylori for $6 \mathrm{~h}$. The normalized relative luciferase activities corresponding to each construct transiently expressed in MKN45 cells that were left untreated or induced with $H$. pylori are shown. The activity of cells transfected with pGL2 Basic without further treatment was designated 1 . The induction values given were calculated as described for panel B. Representative results are shown as means \pm SD calculated from the results of three independent experiments.

MKN45 cells revealed a delayed loss of IкB- $\alpha$ which was maximal at $30 \mathrm{~min}$, followed by restoration of $\mathrm{I} \kappa \mathrm{B}-\alpha$ levels to those of unstimulated MKN45 cells after $3 \mathrm{~h}$ of culture (Fig. 6A).

Induction of IKB- $\alpha$ mRNA expression in MKN45 cells by $H$. pylori. It is possible that $H$. pylori suppressed the transcription of the IкB- $\alpha$ gene. It has been reported that transcription of the I $\mathrm{KB}-\alpha$ gene is regulated by the NF- $\kappa \mathrm{B}$ binding site in the promoter and is activated by NF- $\mathrm{BB}$ p 65 or c-Rel as part of a negative feedback loop (24). To examine whether $H$. pylori

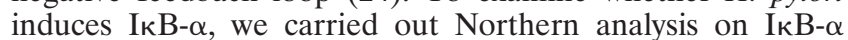
mRNA from MKN45 cells stimulated with $H$. pylori. MKN45 cells were cultured with $H$. pylori or in medium alone, and total RNA was extracted at $1,2,6$, and $24 \mathrm{~h}$. Induction of IкB- $\alpha$ mRNA by $H$. pylori was observed at $1 \mathrm{~h}$ and was maximal at $2 \mathrm{~h}$, decreasing thereafter (Fig. 6B). These results clearly indicate that the decrease in IкB- $\alpha$ protein induced by $H$. pylori resulted not from suppression of transcription but from modulation of posttranscriptional events, probably at the protein level. $\mathrm{Cu}-$ mulatively, these results indicate that $H$. pylori activates MKN45 cells, as reflected by a loss of IкB- $\alpha$ protein and upregulation of its mRNA.

Inhibition of NF-кB activation reduces ICAM-1 expression in response to $\boldsymbol{H}$. pylori infection. PDTC potently inhibits $\mathrm{NF}-\kappa \mathrm{B}$ activation and/or NF- $\mathrm{B}$ interaction with its upstream regulatory binding site, thereby preventing NF-кB-mediated transcriptional activation $(5,21,28,38)$. We used PDTC to show a link between NF- $\mathrm{kB}$ activation and upregulation of ICAM-1 expression in $H$. pylori-infected MKN45 cells. As shown in Fig. 7, PDTC treatment markedly inhibited $H$. pyloriinduced cell surface expression of ICAM-1 (92\% inhibition by $100 \mu \mathrm{M}$ PDTC). However, PDTC had no effect on the viability of MKN45 cells (data not shown).

$H$. pylori infection of epithelial cells increases leukocyte adhesion. MKN45 cells were infected for $6 \mathrm{~h}$ with $H$. pylori. THP-1 cells, PBMCs, or purified neutrophils were used as leukocytes for adhesion experiments. The cells were fluorescently labeled and added to uninfected or 6-h- $H$. pylori-infected MKN45 cells, and after $30 \mathrm{~min}$, the adherence of the leukocytes was measured. As shown in Fig. 8A, H. pylori significantly increased the adhesion of THP-1 cells, PBMCs, and purified neutrophils to MKN45 cells (11.8-, 5.8-, and 5.8-fold, respectively) compared with adhesion to MKN45 cells cultured in medium alone. Neutrophils were treated with an anti-CD18 $\mathrm{MAb}$, an anti-CD54 MAb, or a control IgG1 before addition to H. pylori-infected MKN45 cells, and the amount of adhesive cells was measured under these conditions. As shown in Fig. $8 \mathrm{~B}$, the anti-CD18 MAb and the anti-CD54 MAb significantly 


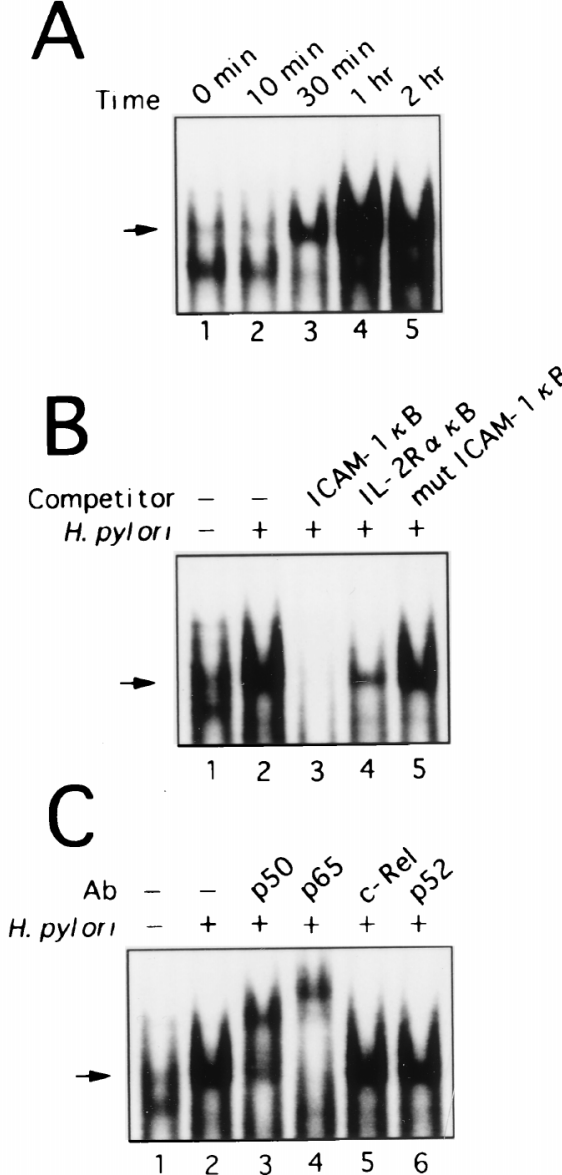

FIG. 4. H. pylori induces a prominent NF- $\mathrm{kB}$ binding complex in MKN45 cells. (A) The time course of NF-KB activation in MKN45 cells infected with $H$. pylori was evaluated using EMSA. (B) Sequence specificity of NF-кB binding activity. The NF-кB probe was incubated with nuclear extracts from unstimulated (lane 1) or $H$. pylori-stimulated MKN45 cells (lanes 2 to 5 ) without (lane 2) or with a 100-fold excess of cold wild-type probes (lanes 3 and 4) or a 100-fold excess of mutant probe (lane 5). (C) Anti-p65 and anti-p50 sera recognize $H$. pylori-stimulated $\mathrm{\kappa B}$ binding complex in nuclear extracts from MKN45 cells. The $\mathrm{\kappa B}$ probe was incubated with nuclear extracts from MKN45 cells that were left unstimulated (lane 1) or cocultured with $H$. pylori (lanes 2 to 6 ). The nuclear extracts were preincubated for 45 min with antibodies (Ab) against p50 (lane 3), p65 (lane 4), c-Rel (lane 5), or p52 (lane 6). The arrow indicates the location of induced $\mathrm{\kappa B}$ binding complex.

decreased the adhesion of neutrophils to $H$. pylori-infected MKN45 cells, whereas the control IgG1 did not.

\section{DISCUSSION}

ICAM-1 is one of several cell adhesion molecules that belong to the immunoglobulin superfamily and serve as ligands for the $\beta_{2}$ integrins, lymphocyte function-associated antigen-1 (LFA-1, also referred to as CD11a/CD18), and Mac-1 (CD11b/ CD18). In contrast to LFA-1, which is constitutively expressed on leukocytes, ICAM-1 is an inducible cell surface glycoprotein expressed at a low level on a wide variety of cells, including leukocytes, vascular endothelium, fibroblasts, and certain epithelial cells. However, ICAM-1 expression is dramatically increased at sites of inflammation, providing important means of regulating cell-cell interactions and thereby presumably inflammatory responses. The function and indeed the importance of leukocyte adhesion in the generation and mainte-
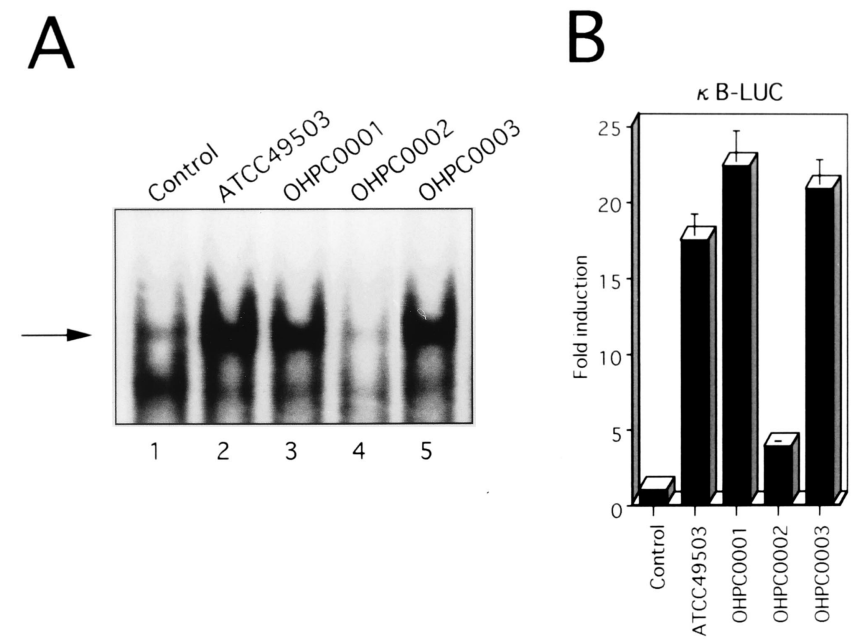

FIG. 5. cag $\mathrm{PAI}^{+} H$. pylori strain-induced ICAM-1 gene expression is specific for the NF- $\mathrm{B}$ region. (A) cag $\mathrm{PAI}^{+} H$. pylori strains show enhanced stimulation of $\mathrm{\kappa B}$ binding activity in MKN45 cells compared with a cag $\mathrm{PAI}^{-} H$. pylori strain. Equal protein concentrations of nuclear extracts from MKN45 cells that were left unstimulated or cocultured with $H$. pylori were analyzed for $\kappa \mathrm{B}$ binding by EMSA. The $\kappa \mathrm{B}$ probe was incubated with nuclear extracts from MKN45 cells that were left unstimulated (lane 1) or were cocultured either with the cag $\mathrm{PAI}^{+}$ H. pylori strain ATCC 49503 (lane 2), OHPC0001 (lane 3), or OHPC0003 (lane 5 ) or with the cag $\mathrm{PAI}^{-}$strain OHPC0002 (lane 4). The arrow indicates the position of the induced $\kappa \mathrm{B}$ binding complex. (B) A chimeric luciferase gene ( $\kappa$ B-LUC) was transfected into MKN45 cells, followed by stimulation with cag $\mathrm{PAI}^{+}$or cag $\mathrm{PAI}^{-}$H. pylori strains $6 \mathrm{~h}$ prior to harvesting of the cells for the luciferase assay.

nance of inflammation have been demonstrated in numerous animal experimental systems using blocking MAbs directed against ICAM-1 as well as ICAM-1 knockout mice.

Researchers in several laboratories have demonstrated the expression of ICAM-1 in chronic gastritis associated with $H$. pylori in vivo $(12,16,17)$. However, the mechanism whereby $H$. pylori induces the expression of ICAM-1 remains largely unknown. This study was therefore designed to evaluate ICAM-1 expression on gastric epithelial cells exposed to $H$. pylori in vitro.

First, we observed that $H$. pylori stimulated significant increases in steady-state mRNA levels and cell surface expression of ICAM-1 in gastric epithelial cells. Next, we investigated the molecular mechanisms by which ICAM-1 gene expression is regulated upon the exposure of gastric epithelial cells to $H$. pylori strains. TNF- $\alpha$ - and gamma interferon (IFN- $\gamma$ )-induced activation of ICAM-1 have been reported to require different transcription factors. Hou et al. (18) and Ledebur and Parks (25) demonstrated that TNF- $\alpha$-induced activation of the ICAM-1 promoter required a variant NF-кB site, 178 to 187 nucleotides upstream of the transcription start site. In contrast, Look and coworkers (26) demonstrated that the IFN- $\gamma$ response element located at nucleotides -76 to -66 of the ICAM-1 5'-flanking region conferred IFN- $\gamma$ responsiveness. The IFN- $\gamma$-induced DNA binding complex contained STAT1 $\alpha$ (18). The data presented here indicate that the NF-кB binding sequence in the ICAM-1 promoter is required for $H$. pyloriinduced ICAM-1 upregulation, whereas the IFN- $\gamma$ response element was not essential.

cag $\mathrm{PAI}^{+}$strains, unlike cag $\mathrm{PAI}^{-}$strains, provoke potentially damaging inflammatory responses in infected host tissue and induce the synthesis of IL-8 in gastric biopsy specimens and cultured cells $(8,10,32)$. Our study shows that the NF-кB p50-p65 heterodimer is activated in gastric epithelial cells in 


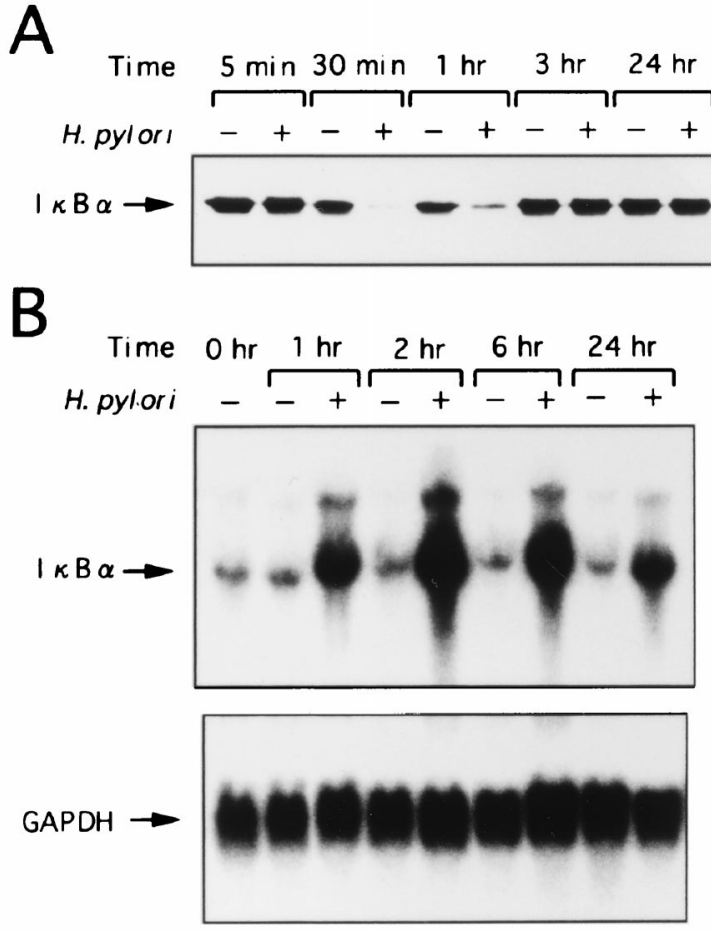

FIG. 6. (A) Kinetic analysis of IкB- $\alpha$ activity in MKN45 cells cultured without $(-)$ or with $(+) H$. pylori for the indicated times. Degradation of IкB- $\alpha$ is seen at 30 min after stimulation of MKN45 cells with $H$. pylori. Restoration of IKB- $\alpha$ in H. pylori-stimulated MKN45 cells to levels comparable to those in unstimulated MKN45 cells is seen after $3 \mathrm{~h}$ of culture. (B) Induction of ІкB- $\alpha$ mRNA in MKN45 cells by $H$. pylori. MKN45 cells were cultured without $(-)$ or with $(+) H$. pylori for the indicated times $(1,2,6$, and $24 \mathrm{~h})$. Total RNA was assessed for IкB- $\alpha$ expression. Equal loading was assessed by hybridization of stripped blots with a probe for GAPDH.

response to $\mathrm{PAI}^{+}$strains of $H$. pylori. Compared to a cag $\mathrm{PAI}^{-}$ $H$. pylori strain, the more-virulent $c a g \mathrm{PAI}^{+}$strains showed an enhanced ability to induce NF- $\mathrm{B}$ binding activity, paralleling observations that increased ICAM-1 induction in MKN45 cells

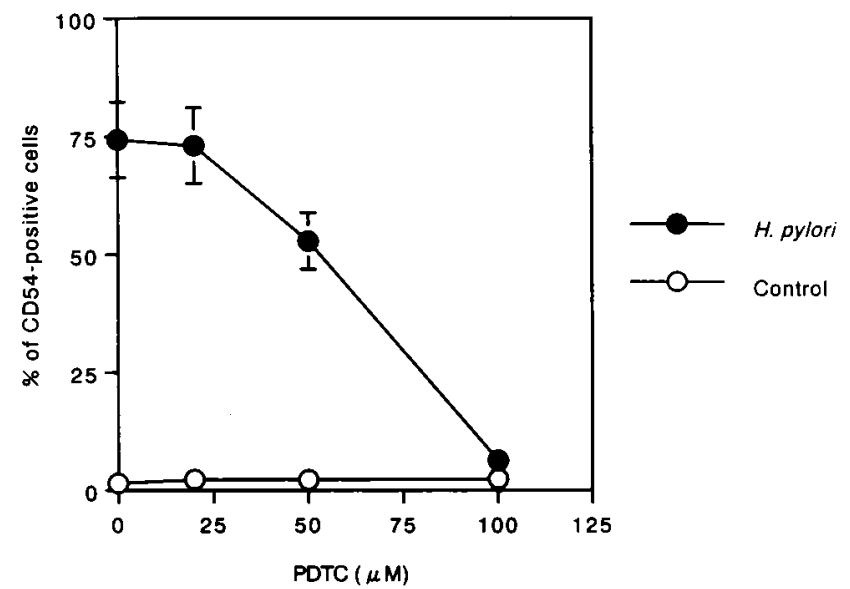

FIG. 7. PDTC (which inhibits NF-кB activation) reduces cell surface expression of ICAM-1 in response to $H$. pylori infection of MKN45 cells. MKN45 cells were pretreated with PDTC $(20,50$, or $100 \mu \mathrm{M})$ for $1 \mathrm{~h}$ prior to $H$. pylori infection. Cells were subsequently infected with $H$. pylori in the presence of PDTC for $24 \mathrm{~h}$. ICAM-1 levels on harvested cells were measured. Data are expressed as means \pm standard deviations $(n=3)$.

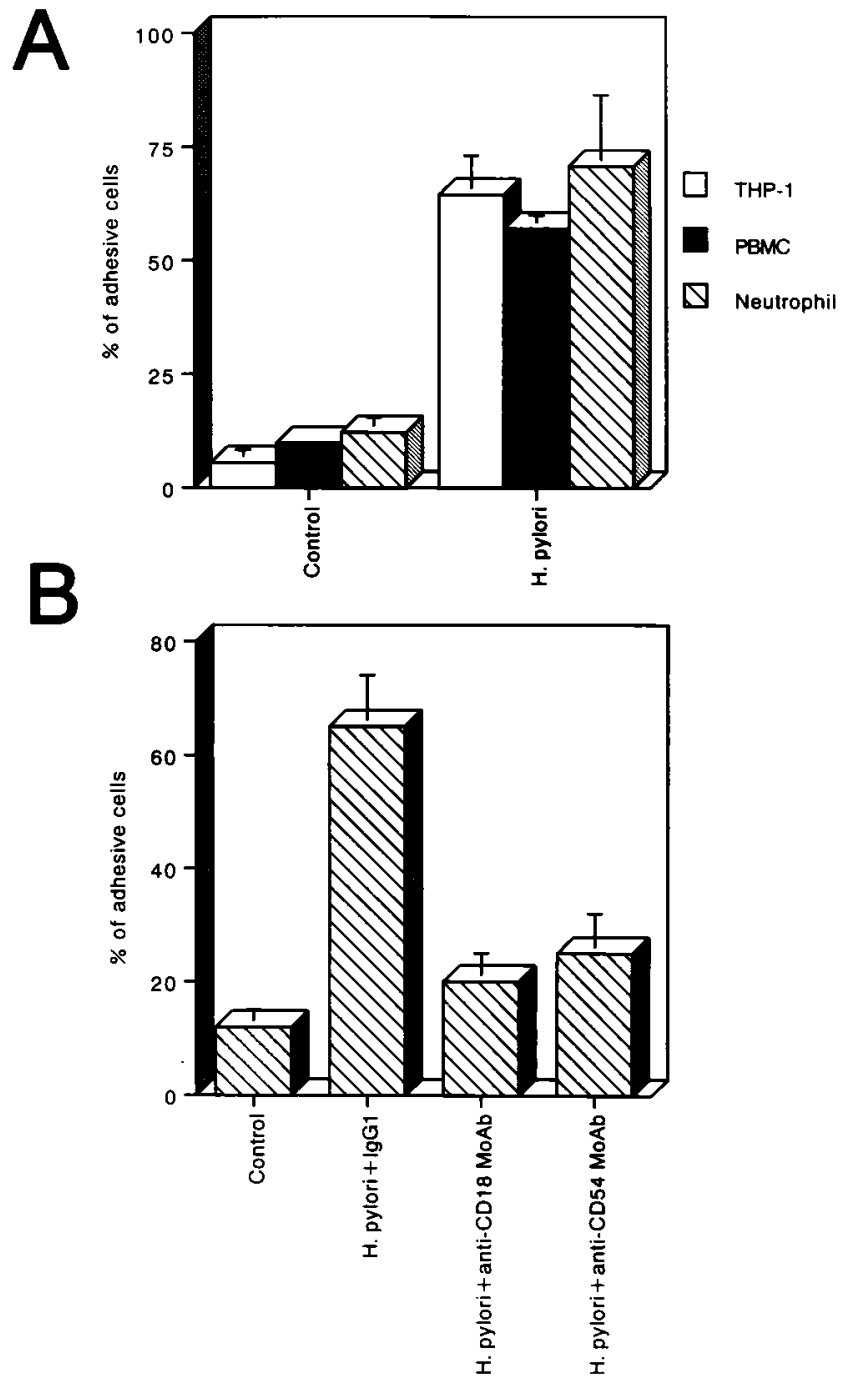

FIG. 8. H. pylori induces increased leukocyte adhesion to MKN45 cells. (A) THP-1 cells, PBMCs, or neutrophils were deposited on untreated or 6-h H. pylori (500 organisms/cell)-infected MKN45 cells and allowed to adhere for $30 \mathrm{~min}$. After cell lysis, fluorescence intensity was measured and expressed for each condition as the percentage of adhesive cells compared with $100 \%$ deposited cells. (B) Inhibitory effects of an anti-CD18 MAb and an anti-CD54 MAb on the adhesion of neutrophils to $H$. pylori-infected MKN45 cells. Neutrophils were previously treated with either an anti-CD18 MAb, an anti-CD54 MAb, or a control IgG1 and were then deposited on MKN45 cells that had been infected with $H$. pylori for $6 \mathrm{~h}$. After cell lysis, fluorescence intensity was measured. In these representative experiments, $n=4$ for each group (means \pm standard deviations).

was cag $\mathrm{PAI}^{+}$strain specific. Along these lines, increased IL-8 expression in epithelial cells in response to cag $\mathrm{PAI}^{+} H$. pylori strains may result from increased NF- $\mathrm{B}$ binding to the IL-8 promoter (33). H. pylori infection of the gastric epithelium, therefore, utilizes similar mechanisms to regulate the orchestrated production of ICAM-1 and IL-8.

Like many other NF- $\mathrm{KB}$ activators, $H$. pylori induced the degradation of $\mathrm{I} \kappa \mathrm{B}-\alpha$ in gastric epithelial cells. Degradation of $\mathrm{I} \kappa \mathrm{B}-\alpha$ in $H$. pylori-induced epithelial cells was associated with translocation of NF- $\kappa$ B and increased levels of IкB- $\alpha$ mRNA. Activated NF- $\kappa \mathrm{B}$ was evident within 30 min of bacterial infection and was pronounced at $1 \mathrm{~h}$. These findings are consistent with the NF-кB activation observed in $H$. pylori-infected epi- 
thelial cells before ICAM-1 mRNA levels are increased, followed in turn by increased cell surface ICAM-1 expression. Furthermore, the blocking of NF- $\mathrm{B}$ activation by PDTC markedly inhibited cell surface ICAM-1 expression after $H$. pylori infection. These findings suggest that NF- $\mathrm{KB}$ activation may be a necessary prerequisite for increased epithelial-cell ICAM-1 expression in response to bacterial infection by $H$. pylori.

Our experiments using cell-free $H$. pylori culture supernatants suggest that the activation of ICAM-1 expression in gastric epithelial cells might not be mediated by a soluble product released from the bacterium. Other investigators have reported that direct contact with live $H$. pylori is indispensable for IL-8 production by gastric epithelial cells $(1,22)$. Expression of ICAM-1 was upregulated in vitro by inflammatory cytokines, including IL-1 and TNF- $\alpha(20,23,25,36)$. These inflammatory cytokines increase in the gastric mucosa of patients with chronic gastritis associated with $H$. pylori. Therefore, these cytokines produced in response to $H$. pylori infection may participate in the expression of this cell adhesion molecule. However, $H$. pylori could not induce the production of IL-1 or TNF- $\alpha$ by MKN45 cells (data not shown). Thus, gastric epithelial cells expressed ICAM-1 only through direct infection with $H$. pylori in vitro.

The finding that $H$. pylori is a potent activator of NF- $\mathrm{BB}$ has important implications, since other NF- $\mathrm{B}$-responsive genes, including those encoding IL-8, TNF- $\alpha$, IL-1, and IL-6, have been found to be elevated in the gastric mucosa of persons with H. pylori $(9,11,13,30)$. H. pylori-induced NF- $\mathrm{B}$ activation and the subsequent upregulation of ICAM-1 and cytokines could contribute to inflammatory-cell recruitment and retention at sites of infection. Because of its pivotal role in inflammation, $\mathrm{NF}-\kappa \mathrm{B}$ will be an obvious target for new types of anti-inflammatory treatments for $H$. pylori-induced gastritis. Blocking the activation of NF- $\mathrm{BB}$, as by use of PDTC, may prevent the early events in the inflammatory cascade, decreasing $H$. pylori-induced inflammation and subsequent gastric injury.

In conclusion, we showed that $H$. pylori is able to directly induce epithelial ICAM-1 expression, which mediates the adhesion of leukocytes to epithelium and may be important in the initiation and maintenance of gastric inflammation in $\mathrm{H}$. pylori gastritis.

\section{ACKNOWLEDGMENTS}

The expert technical assistance of M. Yamamoto and M. Sasaki is gratefully acknowledged. We thank T. Kitahora for providing several clinical isolates of $H$. pylori, and we thank J. Fujisawa, T. K. Kishimoto, and D. W. Ballard for providing plasmids.

This work was supported in part by a Grant-in-Aid for Encouragement of Young Scientists from the Ministry of Education, Science, Sports and Culture of Japan and by the Uehara Memorial Foundation.

\section{REFERENCES}

1. Aihara, M., D. Tsuchimoto, H. Takizawa, A. Azuma, H. Wakebe, Y. Ohmoto, K. Imagawa, M. Kikuchi, N. Mukaida, and K. Matsushima. 1997. Mechanisms involved in Helicobacter pylori-induced interleukin- 8 production by a gastric cancer cell line, MKN45. Infect. Immun. 65:3218-3224.

2. Antalis, T. M., and D. Godbolt. 1991. Isolation nuclei from hematopoietic cell types. Nucleic Acids Res. 19:4301.

3. Benham, F. J., S. Hodgkinson, and K. E. Davies. 1984. A glyceraldehyde-3phosphate dehydrogenase pseudogene on the short arm of the human $\mathrm{X}$ chromosomes defines a multigene family. EMBO J. 3:2635-2640.

4. Blaser, M. J. 1992. Hypotheses on the pathogenesis and natural history of Helicobacter pylori-induced inflammation. Gastroenterology 102:720-727.

5. Brennan, P., and L. A. O'Neill. 1996. 2-Mercaptoethanol restores the ability of nuclear factor $\kappa \mathrm{B}(\mathrm{NF}-\kappa \mathrm{B})$ to bind DNA in nuclear extracts from interleukin 1-treated cells incubated with pyrrolidine dithiocarbamate (PDTC). Evidence for oxidation of glutathione in the mechanism of inhibition of NF-кB by PDTC. Biochem. J. 320:975-981.
6. Censini, S., C. Lange, Z. Xiang, J. E. Crabtree, P. Ghiara, M. Borodovsky, R. Rappuoli, and A. Covacci. 1996. cag, a pathogenicity island of Helicobacter pylori, encodes type I-specific and disease-associated virulence factors. Proc. Natl. Acad. Sci. USA 93:14648-14653.

7. Cover, T. L., and M. J. Blaser. 1992. Helicobacter pylori and gastroduodenal disease. Annu. Rev. Med. 43:135-145.

8. Crabtree, J. E., A. Covacci, S. M. Farmery, Z. Xiang, D. S. Tompkins, S. Perry, I. J. D. Lindley, and R. Rappuoli. 1995. Helicobacter pylori-induced interleukin-8 expression in gastric epithelial cells is associated with CagApositive phenotype. J. Clin. Pathol. 48:41-45.

9. Crabtree, J. E., J. I. Wyatt, L. K. Trejdosiewicz, P. Peichl, P. H. Nichols, N. Ramsay, J. N. Primrose, and I. J. D. Lindley. 1994. Interleukin-8 expression in Helicobacter pylori-infected, normal, and neoplastic gastroduodenal mucosa. J. Clin. Pathol. 47:61-66.

10. Crabtree, J. E., S. M. Farmery, I. J. D. Lindley, N. Figura, P. Peichl, and D. S. Tompkins. 1994. CagA/cytotoxic strains of Helicobacter pylori and interleukin-8 in gastric epithelial cell lines. J. Clin. Pathol. 47:945-950.

11. Crabtree, J. E., T. M. Shallcross, R. V. Heatley, and J. I. Wyatt. 1991. Mucosal tumour necrosis factor $\alpha$ and interleukin-6 in patients with Helicobacter pylori-associated gastritis. Gut 32:1473-1477.

12. El Kaissouni, J., M. C. Bene, and G. C. Faure. 1998. Activation of epithelial cells in gastritis. Digestion 59:53-59.

13. Gionchetti, P., D. Vaira, M. Campieri, J. Holton, M. Menegatti, A. Belluzzi, E. Bertinelli, M. Ferretti, C. Brignola, M. Miglioli, and L. Barbara. 1994. Enhanced mucosal interleukin- 6 and -8 in Helicobacter pylori-positive dyspeptic patients. Am. J. Gastroenterol. 89:883-887.

14. Graham, D. Y. 1992. Pathogenic mechanisms leading to Helicobacter pyloriinduced inflammation. Eur. J. Gastroenterol. Hepatol. 4:S9-S16.

15. Haskill, S., A. A. Beg, S. M. Tompkins, J. S. Morris, A. D. Yurochko, A. Sampson-Johannes, K. Mondal, P. Ralph, and A. S. Baldwin, Jr. 1991. Characterization of an immediate-early gene induced in adherent monocytes that encodes IкB-like activity. Cell 65:1281-1289.

16. Hatz, R. A., G. Rieder, M. Stolte, E. Bayerdorffer, G. Meimarakis, F.-W. Schildberg, and G. Enders. 1997. Pattern of adhesion molecule expression on vascular endothelium in Helicobacter pylori-associated antral gastritis. Gastroenterology 112:1908-1919.

17. Higuchi, K., T. Arakawa, T. Uchida, K. Nakagawa, S. Nakamura, T. Matsumoto, T. Fukuda, K. Kobayashi, and T. Kuroki. 1997. In situ expression of cell adhesion molecules in chronic gastritis with Helicobacter pylori infection. J. Clin. Gastroenterol. 25:S215-S221.

18. Hou, J., V. Baichwal, and Z. Cao. 1994. Regulatory elements and transcription factors controlling basal and cytokine-induced expression of the gene encoding intercellular adhesion molecule 1. Proc. Natl. Acad. Sci. USA 91:11641-11645.

19. Huang, J., P. W. O'Toole, P. Doig, and T. J. Trust. 1995. Stimulation of interleukin-8 production in epithelial cell lines by Helicobacter pylori. Infect. Immun. 63:1732-1738.

20. Kaiserlian, D., D. Rigal, J. Abello, and J. P. Revillard. 1991. Expression, function and regulation of the intercellular adhesion molecule-1 (ICAM-1) on human intestinal epithelial cell lines. Eur. J. Immunol. 21:2415-2421.

21. Kawai, M., R. Nishikomori, E. Y. Jung, G. Tai, C. Yamanaka, M. Mayumi, and T. Heike. 1995. Pyrrolidine dithiocarbamate inhibits intercellular adhesion molecule-1 biosynthesis induced by cytokines in human fibroblasts. J. Immunol. 154:2333-2341.

22. Keates, S., Y. S. Hitti, M. Upton, and C. P. Kelly. 1997. Helicobacter pylori infection activates NF-кB in gastric epithelial cells. Gastroenterology 113: 1099-1109.

23. Kvale, D., P. Krajci, and P. Brandtzaeg. 1992. Expression and regulation of adhesion molecules ICAM-1 (CD54) and LFA-3 (CD58) in human intestinal epithelial cell lines. Scand. J. Immunol. 35:669-676.

24. Le Bail, O., R. Schmidt-Ullrich, and A. Israel. 1993. Promoter analysis of the gene encoding the I $\mathrm{B}-\alpha / \mathrm{MAD} 3$ inhibitor of NF- $\kappa \mathrm{B}$ : positive regulation by members of the rel/NF-кB family. EMBO J. 12:5043-5049.

25. Ledebur, H. C., and T. P. Parks. 1995. Transcriptional regulation of the intercellular adhesion molecule-1 gene by inflammatory cytokines in human endothelial cells. Essential roles of a variant NF-кB site and p65 homodimers. J. Biol. Chem. 270:933-943.

26. Look, D. C., M. R. Pelletier, and M. J. Holtzman. 1994. Selective interaction of a subset of interferon- $\gamma$ response element-binding proteins with the intercellular adhesion molecule-1 (ICAM-1) gene promoter controls the pattern of expression on epithelial cells. J. Biol. Chem. 269:8952-8958.

27. Moss, S. F., S. Legon, J. Davies, and J. Calam. 1994. Cytokine gene expression in Helicobacter pylori-associated antral gastritis. Gut 35:1567-1570.

28. Munoz, C., D. Pascual-Salcedo, M. C. Castellanos, A. Alfranca, J. Aragones, A. Vara, M. J. Redondo, and M. O. de Landazuri. 1996. Pyrrolidine dithiocarbamate inhibits the production of interleukin-6, interleukin-8, and granulocyte-macrophage colony-stimulating factor by human endothelial cells in response to inflammatory mediators: modulation of NF- $\mathrm{B}$ and AP-1 transcription factors activity. Blood 88:3482-3490.

29. NIH Consensus Conference. 1994. Helicobacter pylori in peptic ulcer disease. NIH Consensus Development Panel on Helicobacter pylori in Peptic Ulcer Disease. JAMA 272:65-69. 
30. Noach, L. A., N. B. Bosma, J. Jansen, F. J. Hoek, S. J. H. van Deventer, and G. N. J. Tytgat. 1994. Mucosal tumor necrosis factor- $\alpha$, interleukin-1 $\beta$, and interleukin-8 production in patients with Helicobacter pylori infection. Scand. J. Gastroenterol. 29:425-429.

31. Nomura, A., G. N. Stemmermann, P. H. Chyou, I. Kato, G. I. Perez-Perez, and M. J. Blaser. 1991. Helicobacter pylori infection and gastric carcinoma among Japanese Americans in Hawaii. N. Engl. J. Med. 325:1132-1136.

32. Sharma, S. A., M. K. R. Tummuru, G. G. Miller, and M. J. Blaser. 1995. Interleukin-8 response of gastric epithelial cell lines to Helicobacter pylori stimulation in vitro. Infect. Immun. 63:1681-1687.

33. Sharma, S. A., M. K. R. Tummuru, M. J. Blaser, and L. D. Kerr. 1998. Activation of IL-8 gene expression by Helicobacter pylori is regulated by transcription factor nuclear factor- $\mathrm{B}$ in gastric epithelial cells. J. Immunol. 160:2401-2407.

34. Suzuki, T., H. Hirai, T. Murakami, and M. Yoshida. 1995. Tax protein of HTLV-1 destabilizes the complexes of NF- $\mathrm{B}$ and I $\mathrm{B}-\alpha$ and induces nuclear translocation of NF-кB for transcriptional activation. Oncogene 10: 1199-1207.

Editor: J. D. Clements
35. Tummuru, M. K. R., S. A. Sharma, and M. J. Blaser. 1995. Helicobacter pylori pic $\mathrm{B}$, a homologue of the Bordetella pertussis toxin secretion protein, is required for induction of IL-8 in gastric epithelial cells. Mol. Microbiol. 18:867-876.

36. Voraberger, G., R. Schafer, and C. Stratowa. 1991. Cloning of the human gene for intercellular adhesion molecule 1 and analysis of its 5 '-regulatory region. Induction by cytokines and phorbol ester. J. Immunol. 147:27772786

37. Wada, A., N. Mori, K. Oishi, H. Hojo, Y. Nakahara, Y. Hamanaka, M. Nagashima, I. Sekine, K. Ogushi, T. Niidome, T. Nagatake, J. Moss, and T. Hirayama. 1999. Induction of human $\beta$-defensin- 2 mRNA expression by Helicobacter pylori in human gastric cell line MKN45 cells on cag pathogenicity island. Biochem. Biophys. Res. Commun. 263:770-774.

38. Ziegler-Heitbrock, H. W., T. Sternsdorf, J. Liese, B. Belohradsky, C. Weber, A. Wedel, R. Schreck, P. Bauerle, and M. Strobel. 1993. Pyrrolidine dithiocarbamate inhibits NF-kB mobilization and TNF production in human monocytes. J. Immunol. 151:6986-6993. 